\title{
Association of Marginal Leaf Scorch with Sodium Accumulation in Salt-stressed Peach
}

\author{
Bedri Karakas, Riccardo Lo Bianco, and Mark Rieger \\ Department of Horticulture, University of Georgia, Athens, GA 30602-7273
}

Additional index words. Prunus persica, salinity, chloride, ion toxicity

\begin{abstract}
The effect of specific ion toxicity during salt stress was tested in the present study. The experiment was repeated twice, in 1996 and 1998, with 'Nemaguard' peach seedlings and rooted cuttings grown in hydroponics under two $\mathrm{NaCl}$ concentrations (50 and $30 \mathrm{~mm})$. Foliage was separated in symptomatic and symptomless leaves and the amount of sodium $\left(\mathrm{Na}^{+}\right)$and chloride $\left(\mathrm{Cl}^{-}\right)$was determined. Significantly higher $\mathrm{Na}^{+}$content was found in symptomatic than in symptomless leaves in both experiments, whereas in only two of the six cases was $\mathrm{Cl}^{-}$content higher in symptomatic than in symptomless leaves. The $\mathrm{Na}^{+}$ threshold for leaf scorch was somewhere between 4 and $6 \mathrm{mg}^{-1} \mathrm{~g}^{-1}$ dry weight. Results indicated that $\mathrm{Na}^{+}$accumulation, rather than $\mathrm{Cl}^{-}$accumulation, was associated with the familiar marginal and interveinal scorch symptoms seen in salt-stressed peach leaves.
\end{abstract}

Peach $[$ Prunus persica $(\mathrm{L}$.) Batsch.] is relatively sensitive to soil salinity compared with other crop plants (Maas, 1987, 1993). As with most woody species, its response to salinity not only depends on the osmotic potential of the soil water, but also on the toxic effects of specific ions (Bernstein, 1965). Specific ion toxicity results in yield losses significantly greater than those predicted from osmotic effects alone, and is directly responsible for marginal and interveinal scorch symptoms in peach leaves (Bernstein, 1965). Early research on salinity in peach suggested that accumulation of chloride $\left(\mathrm{C1}^{-}\right)$, rather than sodium $\left(\mathrm{Na}^{+}\right)$or sulfate, in leaves caused leaf scorch (Wadleigh et al., 1951). Further research on several stone fruit species supported the conclusion that $\mathrm{C1}^{-}$accumulation caused leaf scorch (Bernstein et al., 1956), and this paradigm was later applied to several fruit species, including grapes (Vitis vinifera L.) (Bernstein et al., 1969), strawberry (Fragaria $\times$ ananassa Duch.) (Bernstein, 1965), citrus (Citrus sp.) (Walker and Douglas, 1983), and avocado (Persea americana L.) (Bingham et al., 1968). The association of $\mathrm{Cl}^{-}$accumulation with leaf scorch has led to research focused on exclusion of leaf $\mathrm{Cl}^{-}$as a means of reducing salt stress (Rogers et al., 1997; Walker and Douglas, 1983). However, $\mathrm{Na}^{+}$rather than $\mathrm{C1}^{-}$has been associated with leaf scorch in Japanese plum (Prunus salicina Lindl.) (Ziska et al., 1991) and reduced photosynthesis in 'Valencia' orange [Citrus sinensis (L.) Osb.] (Lloyd et al., 1989). Furthermore, $\mathrm{Na}^{+}$and $\mathrm{Cl}^{-}$may act synergistically to produce greater toxicity than when either ion is applied alone (Martin and Koebner, 1995).

Received for publication 12 Feb. 1999. Accepted for publication 9 June 1999. The cost of publishing this paper was defrayed in part by the payment of page charges. Under postal regulations, this paper therefore must be hereby marked advertisement solely to indicate this fact.
Our earlier research indicated that paclobutrazol (PBZ) ameliorated the effects of salt stress on peach by reducing leaf accumulation of $\mathrm{Na}^{+}$and $\mathrm{Cl}^{-}$(Abou El-Khashab et al., 1997). Subsequently, we performed hydroponics experiments using PBZ and gibberellic acid (GA) (an antagonist of PBZ) to determine whether $\mathrm{Na}^{+}$and/or $\mathrm{Cl}^{-}$was excluded or tolerated differently in peach leaves treated with these growth regulators during $\mathrm{NaCl}$ stress. The experiments involved separating leaves into those with (scorched), and without symptoms (normal), measuring their $\mathrm{Na}^{+}$and $\mathrm{Cl}^{-}$contents, and relating this to the presence/absence of leaf scorch. These experiments failed to demonstrate consistent effects of $\mathrm{PBZ}$ or $\mathrm{GA}$ on $\mathrm{Na}^{+}$and $\mathrm{Cl}^{-}$uptake or accumulation in leaves, but the data suggested that leaf $\mathrm{Na}^{+}$content (and not $\mathrm{Cl}^{-}$) was closely correlated with leaf scorch in peach regardless of growth-regulator treatment. This paper presents a portion of the data collected in these experiments to test the hypothesis that $\mathrm{Na}^{+}$ accumulation in peach leaves is better correlated with expression of leaf scorch than is $\mathrm{Cl}^{-}$ accumulation.

\section{Materials and Methods}

The experiment was conducted during Jan.Mar. 1996 and repeated in Mar.-June 1998. The two experiments differed in two respects: 1) in 1996 'Nemaguard' seedlings were used, whereas in 1998 rooted cuttings of 'Nemaguard' were used, and 2) the $\mathrm{NaCl}$ concentration was $50 \mathrm{~mm}$ in 1996 and $30 \mathrm{~mm}$ in 1998. Both experiments were conducted in a greenhouse in Athens, Ga. $\left(34^{\circ} \mathrm{N}\right.$ lat. and $83^{\circ} 40^{\prime} \mathrm{W}$ long.), with $\approx 70 \%$ integrated daily solar radiation transmission, natural photope$\operatorname{riod}($ range $=10.5$ to $13.5 \mathrm{~h}$ ), and temperatures ranging from 22 to $35^{\circ} \mathrm{C}$. In both cases, 48 plants were transplanted to 8-L hydroponic containers filled with nutrient solution, the composition of which was described by Jones (1985). Two plants were placed in each con- tainer, which constituted one experimental unit. Each experiment was a factorial combination of two $\mathrm{NaCl}$ levels ( 0 and 50 or $30 \mathrm{~mm}$ ) and three growth-regulator treatments (none, PBZ, GA), with four replications. The growthregulator treatments produced occasional significant, yet inconsistent, effects on growth and ion accumulation; thus, data could not be pooled across growth-regulator treatments. In the interest of brevity, growth-regulator effects per se are not discussed. Plants were sprayed with PBZ (200 mg: $\left.\mathrm{L}^{-1}\right)$, GA (200 $\mathrm{mg} \cdot \mathrm{L}^{-1}$ ), or water twice at an interval of $15 \mathrm{~d}$ starting the day that treatment with $\mathrm{NaCl}$ began. Exposure to $\mathrm{NaCl}$ treatments began after acclimation of plants to hydroponics for 2 weeks and was stopped after $\approx 7$ (1996) or 11 (1998) weeks. Containers were arranged in a randomized complete-block design.

At the end of each experiment, leaves were divided into symptomless and symptomatic (scorched) classes, and the total leaf area per plant in each class was measured with a leafarea meter (LI-COR LI-3000; LI-COR, Lincoln, Nebr.). Leaves were dried at $70{ }^{\circ} \mathrm{C}$, finely ground, and used for analyses of $\mathrm{Na}^{+}$ and $\mathrm{Cl}^{-}$content. Sodium was determined using a $\mathrm{Na}^{+}$-selective electrode (Corning Science Products, Corning, N.Y.) according to the method of Rieger and Litvin (1998). Chloride was determined using a $\mathrm{Cl}^{-}$-selective electrode (Fisher Scientific, Pittsburgh) after the method of Islam et al. (1983).

The data were analyzed by $t$ test comparing symptomatic and symptomless leaf classes within a given year and growth-regulator treatment using SAS (SAS Institute, Cary, N.C.).

\section{Results and Discussion}

Growth of plants was affected by $\mathrm{NaCl}$ similarly in the 1996 and 1998 experiments. Total, stem, and root dry weight were lower in salt-treated plants than in nonsalinized plants in both experiments regardless of growthregulator treatment, but total leaf dry weight was not affected by $\mathrm{NaCl}$ in either experiment (data not shown). Defoliation of $\mathrm{NaCl}$ treated plants ranged from $2 \%$ to $15 \%$ of the total leaf area per plant in both experiments. Leaf scorch symptoms were evident in $36 \%$ to $64 \%$ of the total leaf area of salt-treated plants in 1996, but in only $22 \%$ to $32 \%$ in 1998 (data not shown). Differences in percentages of canopy leaf scorch between years probably resulted from the higher concentration of $\mathrm{NaCl}$ used in 1996 vs. 1998.

Leaf $\mathrm{Na}^{+}$and $\mathrm{Cl}^{-}$contents increased significantly in response to $\mathrm{NaCl}$ treatment in each experiment (Table 1). Significantly higher $\mathrm{Na}^{+}$content was found in symptomatic than in symptomless leaves regardless of growth-regulator treatment in both experiments. However, in only two of the six cases was $\mathrm{Cl}^{-}$content higher in symptomatic than in symptomless leaves (Table 1). The $\mathrm{Na}^{+}$threshold for leaf scorch was somewhere between 4 and 11 $\mathrm{mg} \cdot \mathrm{g}^{-1}$ dry weight in 1996, and between 2 and $6 \mathrm{mg} \cdot \mathrm{g}^{-1}$ in 1998. Similar results were obtained for 'Nemaguard' rooted cuttings grown in hydroponics in another study in 1997 with 50 
Table 1. Effects of exposure to $\mathrm{NaCl}$ and treatment with paclobutrazol (PBZ) or gibberellic acid (GA) on $\mathrm{Na}^{+}$and $\mathrm{Cl}^{-}$contents of 'Nemaguard' peach seedlings after 7 weeks of exposure to $\mathrm{NaCl}$ (50 mM) in solution in 1996, and of rooted cuttings of 'Nemaguard' after 11 weeks of exposure to $\mathrm{NaCl}$ ( $30 \mathrm{~mm}$ ) in solution in 1998 .

\begin{tabular}{|c|c|c|c|c|c|}
\hline \multirow[b]{4}{*}{ Ion } & \multirow[b]{4}{*}{$\begin{array}{l}\text { Growth } \\
\text { regulator }\end{array}$} & \multicolumn{3}{|c|}{$\mathrm{Na}^{+}$or $\mathrm{Cl}^{-}$content in leaves $\left(\mathrm{mg} \cdot \mathrm{g}^{-1}\right.$ dry wt) } & \multirow{4}{*}{$\begin{array}{c}P>t, \\
\text { symptomless vs. } \\
\text { symptomatic }\end{array}$} \\
\hline & & \multicolumn{3}{|c|}{$\mathrm{NaCl}$ treatment } & \\
\hline & & \multirow[t]{2}{*}{ No } & \multicolumn{2}{|c|}{$\begin{array}{c}\text { Yes } \\
\end{array}$} & \\
\hline & & & $\begin{array}{c}\text { Symptomless } \\
\text { leaves }\end{array}$ & $\begin{array}{c}\text { Symptomatic } \\
\text { (scorched) leaves }\end{array}$ & \\
\hline & & & 1996 & & \\
\hline \multirow[t]{3}{*}{$\mathrm{Na}^{+}$} & None & 0.02 & 4.3 & 11.0 & 0.0001 \\
\hline & PBZ & 0.02 & 5.7 & 12.7 & 0.0024 \\
\hline & GA & 0.01 & 6.4 & 13.5 & 0.0001 \\
\hline \multirow[t]{4}{*}{$\mathrm{Cl}^{-}$} & None & 0.55 & 19.5 & 18.1 & 0.4408 \\
\hline & PBZ & 0.64 & 21.4 & 25.1 & 0.1760 \\
\hline & GA & 0.62 & 15.7 & 19.5 & 0.0037 \\
\hline & & & 1998 & & \\
\hline \multirow[t]{3}{*}{$\mathrm{Na}^{+}$} & None & 0.47 & 1.8 & 6.2 & 0.0004 \\
\hline & PBZ & 0.62 & 1.9 & 6.4 & 0.0001 \\
\hline & GA & 0.49 & 2.1 & 5.9 & 0.0002 \\
\hline \multirow[t]{3}{*}{$\mathrm{Cl}^{-}$} & None & 0.44 & 7.6 & 8.5 & 0.2158 \\
\hline & PBZ & 0.37 & 7.1 & 10.1 & 0.0001 \\
\hline & GA & 0.46 & 7.1 & 8.1 & 0.1909 \\
\hline
\end{tabular}

$\mathrm{mm} \mathrm{NaCl}$ added (Rieger, unpublished data), yielding a threshold for leaf scorch at $\mathrm{Na}^{+}$ contents between 3.5 and $6 \mathrm{mg} \cdot \mathrm{g}^{-1}$. Thus, an approximate threshold range for $\mathrm{Na}^{+}$of 4-6 $\mathrm{mg} \cdot \mathrm{g}^{-1}$ was found consistently in three different experiments using 'Nemaguard' peach. In addition to the leaf $\mathrm{Cl}^{-}$content being similar between symptomatic and symptomless leaves in two-thirds of the cases tested, the range of values obtained was much more variable, and showed no overlap between experiments, unlike the data for $\mathrm{Na}^{+}$content (Table 1).

Results indicate that $\mathrm{Na}^{+}$accumulation, rather than $\mathrm{Cl}^{-}$accumulation, above a threshold of $\approx 4-6 \mathrm{mg} \cdot \mathrm{g}^{-1}$, was associated with the familiar marginal and interveinal scorch symptoms seen in salt-stressed peach leaves. This finding is inconsistent with the paradigm that leaf scorch in stone fruits is associated with $\mathrm{Cl}^{-}$ accumulation (Bernstein et al., 1956), but con- sistent with more recent reports that associate $\mathrm{Na}^{+}$accumulation with leaf scorch in Japanese plum (Ziska et al., 1991). Future work on resistance to salt stress in stone fruits should therefore consider exclusion or tolerance of $\mathrm{Na}^{+}$in addition to that of $\mathrm{Cl}^{-}$.

\section{Literature Cited}

Abou El-Khashab, A.M., A.F. El-Sammak, A.A. Elaidy, M.I. Salama, and M. Rieger. 1997. Paclobutrazol reduces some negative effects of salt stress in peach. J. Amer. Soc. Hort. Sci. 122:43-46.

Bernstein, L. 1965. Salt tolerance of fruit crops. U.S. Dept. Agr., Agr. Info. Bul. 292. The influence of rootstock on growth and salt accumulation in stone fruit trees and almonds. Proc. Amer. Soc. Hort. Sci. 68:86-95.

Bernstein, L., C.F. Ehlig, and R.A. Clark. 1969. Effect
Bernstein, L., J.W. Brown, and H.E. Hayward. 1956. of grape rootstocks on chloride accumulation in leaves. J. Amer. Soc. Hort. Sci. 6:584-590.

Bingham, F.T., L.B. Fenn, and J.J. Oertli. 1968. A sandculture study of chloride toxicity to mature avocado trees. Soil Sci. Soc. Amer. Proc. 32:249252.

Jones, J.B. 1985. Growing plants hydroponically. Amer. Biol. Teacher 47:356-358.

Islam, A., G.L. Kerven, and C.J. Asher. 1983. Chloride determination in plant tissue using a solid state chloride ion specific electrode. Commun. in Soil Sci. Plant Anal. 14:645-653.

Lloyd, J., P.E. Kriedemann, and D. Aspinall. 1989. Comparative sensitivity of 'Prior Lisbon' lemon and 'Valencia' orange trees to foliar sodium and chloride concentrations. Plant Cell Environ. 12:529-540.

Maas, E.V. 1987. Salt tolerance of plants, p. 57-75. In: B.R. Christie (ed.). Handbook of plant science in agriculture. vol. 2. CRC Press, Boca Raton, Fla.

Maas, E.V. 1993. Plant growth response to salt stress. vol. 1, p. 279-291. In: H. Lieth and A. Al Masoom (eds.). Towards the rational use of high salinity tolerant plants. Kluwer Academic Publ., The Netherlands.

Martin, P.K. and R.M.D. Koebner. 1995. Sodium and chloride ions contribute synergistically to salt toxicity in wheat. Biol. Plant. 37:265-271.

Rieger, M. and P. Litvin. 1998. Ion selective electrodes for measurement of sodium and chloride in salinity experiments. J. Plant Nutr. 21:205-215.

Rogers, M.E., C.L. Nobel, G.M. Halloran, and M.E. Nicolas. 1997. Selecting for salt tolerance in white clover (Trifolium repens): Chloride ion exclusion and its heritability. New Phytol. 135:645-654.

Wadleigh, C.H., H.E. Hayward, and A.D. Ayers. 1951. First year growth of stone fruit trees on saline substrates. Proc. Amer. Soc. Hort. Sci. 57:31-36

Walker, R.R. and T.J. Douglas. 1983. Effect of salinity level on uptake and distribution of chloride, sodium and potassium ions in citrus plants. Aust. J. Agr. Res. 34:145-153.

Ziska, L.H., T.M. DeJong, G.F. Hoffman, and R.M Mead. 1991. Sodium and chloride distribution in salt-stressed Prunus salicina, a deciduous tree species. Tree Physiol. 8:47-57. 